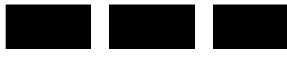 \\ $\square \square$ \\ THE WILLIAM DAVIDSON INSTITUTE \\ AT THE UNIVERSITY OF MICHIGAN
}

\section{UNLOCKING PRODUCTIVE ENTREPRENEURSHIP IN AFRICA'S LEAST DEVELOPED COUNTRIES}

\author{
By: Zuzana Brixiova
}

William Davidson Institute Working Paper Number 990

June 2010 


\title{
Unlocking Productive EnTRePreneurship in AfricA’s Least Developed Countries
}

\author{
Zuzana Brixiova $^{1}$
}

African Development Bank, Development Research Department, Tunis, Tunisia

In Africa's least developed countries (LDCs), escape from poverty and convergence to living standards of more advanced economies depends critically on structural transformation and the emergence of productive entrepreneurship that would accelerate growth and job creation. So far, however, subsistence agriculture has been the main source of employment in these countries, while a dynamic private sector in industry or high value-added services has remained elusive. Utilizing the flow approach to labor markets, this paper complements the empirical literature and numerous surveys on small and medium enterprise (SME) constraints and develops a theoretical framework that examines the main obstacles to entrepreneurship in Africa's LDCs. The paper posits that given the persistent frictions in product and labor markets as well as skill shortages that characterize these economies, development of productive entrepreneurship cannot be left to markets alone. The policy analysis suggests that the state has an important role to play. Welltargeted government interventions including training of potential entrepreneurs and workers can help establish more modern and highly productive SME clusters that Africa's LDCs need.

JEL classification: L26, O1, J64, J68

Keywords: Entrepreneurship, institutions and policies, Africa, LDCs, search model

\footnotetext{
${ }^{1}$ The author thanks Emerta Asaminew, Jan Babecky, Byeongju Jeong, Abdul B. Kamara, Albert Mafusire, Joel Muzima, Abebe Shimeles, participants at the AfDB Research Department seminar, and the 2009 African Economic Conference (Addis Ababa) for helpful discussions and comments. She also thanks an anonymous referee for insightful suggestions that improved the paper. Views expressed are those of the author and do not necessarily reflect those of the African Development Bank. E-mail address: z.brixiova@afdb.org.
} 


\section{Introduction}

For a number of years now, policymakers and researchers have recognized entrepreneurship to be a key driver of economic development through fostering growth, job creation, technology adoption and innovation as well as poverty alleviation. ${ }^{2}$ At the same time, substantial differences across countries in the type of entrepreneurial activities have been also noted, including those in the shares of necessity and opportunity entrepreneurship (Baumol, 1990; Acs, Dessai and Hessels, 2008). Specifically, opportunity entrepreneurs prevail in high-income countries while necessity ones dominate in low-income countries. The more educated entrepreneurs are with opportunity-based firms, while less educated ones are involved out of necessity (Acs et al, 2004). According to Acs and Varga (2005), the opportunity entrepreneurship has a significant positive effect on development, but the necessity one has almost none.

More recently, experiences of transition economies in Central and Eastern Europe, where a successful transition to market hinged on a dynamic private sector and especially new firms, have confirmed the importance of productive (opportunity) entrepreneurship for growth, job creation, competition and innovation. Benefits of productive entrepreneurship extend beyond economic wellbeing, especially when it is narrowly measured by GDP. Success stories of "selfmade" men and women across countries, sectors and cultures inspire hopes in others that in an enabling environment people from all backgrounds can improve their living standards through their own efforts, risk taking, and creativity.

In Africa's least developed countries (LDCs), the potential contribution of entrepreneurship to development has been widely discussed, with the debate going through several stages. ${ }^{3}$ In this context, it needs to be emphasized that entrepreneurship as such has not been limited in Africa, but it is the lack of productive (opportunity) entrepreneurship that has been mostly missing (Rogerson, 2001). Moreover, as Gelb et al. (2007) point out, in many African countries a substantial productivity lag exists between small, often indigenous, firms and larger firms, which are frequently foreign-owned or owned by ethnic minorities. Despite these gaps, in the past many economists had argued that improving infrastructure and basic social indicators is the most pressing priority in Africa's LDCs, putting the primary emphasis on the role of the state in

\footnotetext{
${ }^{2}$ See, for example, Baliamoune-Lutz (2007). Since this paper aims to link entrepreneurship with development, it defines entrepreneurship as in Naudé (2010) to be "...the resource and process whereby individuals utilize opportunities in the market through the creation of new business firms." Leff (1979) provides historical perspective on evolution of research on entrepreneurship and economic development.

${ }^{3}$ Africa's 10 LDCs are Burundi, Central African Republic, Congo Democratic Republic, Ethiopia, Guinea Bissau, Liberia, Malawi, Niger, Sierra Leone and Togo (Eritrea is omitted because of the lack of data). Despite their differences, these economies share features that hamper development of productive entrepreneurship, including (i) low literacy rates and large share of unskilled workers in manufacturing; (ii) weak business environment and application of the rule of law; and (iii) high share of subsistence agriculture in output and employment (Annex I). In contrast to advanced economies, Africa's LDCs have much smaller shares of small and medium-sized enterprises (SMEs) in output and employment. SMEs account for about 30 and 17 percent of employment and output in low income countries, while they account for about 60 and 50 percent, respectively, in advanced economies (Commission on the Private Sector and Development, 2004).
} 
development. In contrast, the role of the private sector predominated in the 1980s and 1990s, when the attention of policymakers turned to market-led development. ${ }^{4}$

Over time, an increasing number of African policymakers and researchers have recognized that with the persistent weaknesses and market failures that characterize Africa's LDCs, development of a productive private sector in these countries cannot be left to markets alone. This is because in Africa's LDCs, successful entrepreneurship is often associated with mere survival rather than involvement in highly productive activities. Entering new activities involves substantial fixed costs and risks which may not be undertaken by private sector without extra incentives and support from the state. In such circumstances, without picking winners, well-targeted government interventions can ease the most biding constraints to productive entrepreneurship and thus facilitate private sector take-off (Bonaglia and Fukasaku, 2007).

Given the importance of SMEs and productive entrepreneurship for development and the facilitating role that the state can play, it is crucial to identify the factors that most impede firm creation in Africa's LDCs. At the same time it needs to be acknowledged that, as Naudé (2010) points out, the relationship between entrepreneurship and development is complex, and further research is needed on links between entrepreneurship, institutions, and development, especially in Africa. ${ }^{5}$ While credit constraints, business environment (including taxation) and infrastructure bottlenecks have dominated the discussion on obstacles facing new firms in Africa's LDCs, skill shortages (both on the side of workers and entrepreneurs) have received less attention. Still, the evidence points to the lack of skills as an important additional constraint to starting new firms. ${ }^{6}$ This paper formalizes the constraints persistent in Africa's LDCs in an analytical framework, which is then used for an evaluation of policies.

The paper is organized as follows. Section 2 presents the model, while Section 3 examines the impact of policies on productive entrepreneurship and skilled employment. Section 4 concludes.

\section{The Model}

The model developed in this section aims at capturing various constraints faced by entrepreneurs in Africa's LDCs with a focus on frictions in the business climate, the labor market and on

\footnotetext{
${ }^{4}$ In recent years, policy makers in LDCs have paid increased attention to fostering private sector development as a key pillar of their national development strategies, which is also reflected in their Poverty Reduction Strategy Papers (Bonaglia and Fukasaku, 2007). Examples of sectors where domestic private enterprises have contributed to poverty alleviation in low income countries include cut flowers in Kenya and leather product in Ethiopia. More generally, in low income countries, high economic growth is accompanied by a more than proportional growth in the share of the formal small and medium enterprise sector (Commission on the Private Sector and Development, 2004).

${ }^{5}$ For example, Balamoune-Lutz (2009) documents this complexity by showing that financial reforms have a positive effect on entrepreneurship and growth at early stages, but have a negative impact at high levels of reforms.

${ }^{6}$ According to the World Bank Enterprise Surveys (2009), the share of firms that identify the skill level of labor as a major constraint to their operations range from $5 \%$ in Liberia to $50 \%$ in Malawi, with an average of $20 \%$ for LDCs and well as for SSA. Labor market regulations and wage setting mechanisms constitute reportedly smaller constraint in these surveys- their impact is examined in detail in Davidson and Henrekson (2002).
} 
shortages of skills. ${ }^{7}$ The model is an expanded version of Brixiova and Asaminew (2009), who in turn build on Snower (1996) and Gelb et al. (2009).

The population is normalized to one and consists of infinitely-lived entrepreneurs and workers, with population shares $\mu$ and $1-\mu$, respectively. All agents are endowed with one unit of time every period, have risk neutral preferences in consumption of a single good, $c$, and cannot save, i.e. consume all their income each period. Firms are created through entrepreneurs' search, at a flow cost $d(x)=x^{2} / 2 \gamma$, units of the consumption good per unit of time, where $\gamma>0$ denotes the efficiency of search. The entrepreneurs find a business opportunity according to a Poisson process with the arrival rate of $x$.

The business opportunities that the entrepreneurs find have potential productivity per worker $z$. The consumption good can thus be produced either through self-employment in the informal sector, with low productivity per worker, $b$, or through firm in the formal sector with high productivity, z. In order to turn the business opportunities into firms, entrepreneurs need to find $\bar{n}$ skilled workers who are in limited supply. Suppressing the time subscript $t$ and denoting $V$ to be the aggregate number of skilled vacancies posted by entrepreneurs, $N$ the number of skilled workers searching for jobs, and $h$ the number of skilled-job matches, the matching function is described as:

$$
h=A \min [N ; V]
$$

where $1>A>0$ is constant. ${ }^{8}$ According to (1), more skilled vacancies or more skilled searching workers lead to more matches. Entrepreneurs with high-productivity business opportunity thus find skilled workers with probability $\rho=A \min \left[\frac{N}{V}, 1\right]$.

\section{Entrepreneurs}

After finding both business opportunity and skilled labor, entrepreneurs produce output according to $y=\varepsilon z \bar{n}$, where $\varepsilon, 0<\varepsilon<1$ characterizes the quality of the business environment in which they operate. Firms earn after-tax profit: $\pi=(1-\tau)(\varepsilon z \bar{n}-w \bar{n})$, where $w$ is the wage of skilled workers and $\tau$ is the profit tax rate. Entrepreneurs who do not find business opportunity or skilled workers continue to search and work as self employed in the informal sector, earning income $b .{ }^{9}$ Firms are destroyed through firm-specific, idiosyncratic productivity shocks arriving at the exogenously given rate $\delta$.

\footnotetext{
${ }^{7}$ While credit constraints are important, they are covered elsewhere. Examples include Li (1998) for developed economies, Brixiova and Kiyotaki (1997) for transition economies, and AfDB and OECD (2005) for Africa.

${ }^{8} A<1$ reflects the limited efficiency of matching, such as that firms searching for skilled works are not fully aware of workers' availability and vice versa.

${ }^{9}$ In this formulation, the model captures the fact that while entrepreneurship itself is abundant in Africa, successful entrepreneurs account for only a fraction of the total population of SMEs (Rogerson, 2001).
} 
To characterize the optimization problems of entrepreneurs, the value function approach is utilized..$^{10}$ Letting $J^{p}$ and $J^{u}$ be the present discounted value of the income stream of an entrepreneur operating a highly productive private firm and of an entrepreneur searching for a business opportunity, respectively, the corresponding Bellman equations are:

$$
\begin{aligned}
& r J^{p}=\pi+\delta\left(J^{u}-J^{p}\right) \\
& r J^{u}=b+\max _{x}\left(-\frac{x^{2}}{2 \gamma}+x\left[\rho\left(J^{p}-J^{u}\right)\right]\right)
\end{aligned}
$$

where $r$ is the exogenously given discount rate. A searching entrepreneur receives the income from self-employment, $b$, finances cost of search of $x^{2} / 2 \gamma$ and expects to open a firm at rate $x \rho$. An entrepreneur running a firm receives profit and expects the firm to exit at rate $\delta$. The utility- maximizing search intensity $x$, which equals the marginal cost of search with the expected benefit, is derived from differentiating equation (3) and is given by:

$$
x=\gamma \rho\left(J^{p}-J^{u}\right)
$$

Hence the search intensity rises with the difference between the values of running a firm and searching, and thus with the level of productivity, $z$. It increases with the efficiency of search, $\gamma$, and the probability of finding skilled workers, $\rho$, which each entrepreneur takes as given.

\section{Workers}

Unskilled, self-employed workers in the informal sector acquire skills demanded in the highly productive private firms at exogenously given rate $\bar{q}$, which costs them $\phi>0$ units of consumption good. In turn, skilled workers then find employment in a high-productivity private firm with probability $\xi=A \min \left[\frac{V}{N}, 1\right]$. Skilled labor is homogeneous and all skilled jobs offer the same wage $w$. Workers who do not obtain skills or do not find skilled jobs continue to work in the informal sector as self-employed and earn constant income $b$, where $0<b<w$. Skilled workers lose their jobs (and skills) at exogenous rate $\delta$.

Denoting $V^{p}$ and $V^{u}$ to be the present discounted value of the income stream of a skilled worker employed in highly productive private firms and the present discounted value of being self-employed in an unskilled job in the informal sector, respectively, gives:

$$
r V^{p}=w+\delta\left(V^{u}-V^{p}\right)
$$

\footnotetext{
${ }^{10}$ In the context of labor markets, this approach is also referred to as matching or flow approach to labor markets. This literature views job creation is as a stable function of the stock of searching workers and vacancies.
} 


$$
r V^{u}=b-\phi+\bar{q} \xi\left(V^{p}-V^{u}\right)
$$

Equation (5) states that a skilled worker receives wage $w$ and expects to go back to selfemployment at rate $\delta$, while according to (6), an unskilled worker obtains income $b$ from selfemployment, obtain skills at cost $\phi$ and expects to find a skilled job at rate $\xi \bar{q}$, where $\bar{q}$ is the rate of skill acquisition and $\xi$ is the probability that skilled workers find skilled jobs.

\section{Wages}

Wages of skilled workers employed in the highly productive firms depend on conditions in the labor market for skilled workers according to:

$$
w=(b-\phi)+k(r+\delta+\bar{q} \xi)
$$

where $k$ is constant. Equation (7) shows that wages depend on the labor market conditions in the market for skilled labor, which are described by the exit rate from self-employment, $\bar{q} \xi$. It is derived from applying the efficiency wage consideration to (5) and (6). This consideration implies that firms choose wage so that the value of being employed exceeds value of being selfemployed by $k \geq 0$. As (7) demonstrates, wages are positively related to informal sector income, $b$, discount rate, $r$, and exit rate from self-employment, $\bar{q} \xi$, but decline with cost of training, $\phi$.

\section{Labor Market “Clearing” Conditions}

Let $\mu$ be the total number of entrepreneurs. Denoting $m_{u}$ as the share of entrepreneurs being self-employed and searching, while $m_{p}$ as the share of entrepreneurs operating businesses, the labor market equilibrium for entrepreneurs satisfies:

$$
\mu=m_{u}+m_{p}
$$

The evolution of number of entrepreneurs searching for business opportunities, $\dot{m}_{u}$, is given by the difference between inflows into the pool of searching entrepreneurs, $\delta\left(\mu-m_{u}\right)$ and the exits from it, $x \rho m_{u}$. Moreover, from (8), $\dot{m}_{p}=-\dot{m}_{u}$.

$$
\dot{m}_{u}=\delta\left(\mu-m_{u}\right)-x \rho m_{u}
$$

Similarly, denoting $n_{u}$ as the number (share) of the unskilled workers (self-employed) in the informal sector and $n_{p}$ as the number of skilled workers employed in highly productive firms, the following labor market equilibrium condition for workers needs to hold:

$$
1-\mu=n_{u}+n_{p}
$$


The evolution of the share of workers working as self-employed in the informal sector can be described as follows:

$$
\dot{n}_{u}=\delta\left(1-\mu-n_{u}\right)-\bar{q} \xi n_{u}
$$

Where $\bar{q} \xi$ is the rate of exit from self-employment while $\delta$ is the inflow rate into it. In the steady state the shares of searching entrepreneurs and workers in the informal sector are constant, i.e. $\dot{n}_{u}=\dot{m}_{u}=0$. Subsequently, these shares satisfy:

$$
\begin{aligned}
& m_{u}=\frac{\delta \mu}{\delta+x \rho} \\
& n_{u}=\frac{\delta(1-\mu)}{\delta+\bar{q} \xi}
\end{aligned}
$$

According to (12), the steady state number of self-employed entrepreneurs who are searching for business opportunities, $m_{u}$, decreases with the exit rate from self-employment, $x \rho$, as well as with the quality of the job-worker match, i.e. lower separation rate $\delta$. At the same time, it increases with the higher share of potential entrepreneurs, $\mu$. Similarly, (13) shows that the steady state equilibrium number of workers who are self-employed in the informal sector and acquiring skills, $n_{u}$, decreases the exit rate from self-employment, $\xi \bar{q}$, and the quality of the match/lower separation rate $\delta$.

The equilibrium in this economy is then characterized by entrepreneurs' effort, by allocations of workers and entrepreneurs, and by the wage rate such that: (i) entrepreneurs choose optimal search effort for business opportunities (x); (ii) wages satisfy (7); (iii) product market clears, and (v) labor market conditions (8), (10), (12) and (13) are met.

To characterize the equilibrium, entrepreneurs' probabilities of finding skilled workers and skilled workers' probabilities of finding skilled jobs need to be specified. Denoting the ratio of skilled vacancies in the private sector to skilled workers searching for jobs as $\theta$, i.e. $\theta=\frac{m_{u} x \bar{n}}{n_{u} \bar{q}}$, where $V=m_{u} x \bar{n}$ and $N=n_{u} \bar{q}$, three cases can be considered: (i) shortages of firms with skilled vacancies, i.e. $\theta<1$; (ii) shortages of skilled workers, i.e. $\theta>1$; and (iii) no shortages, i.e. $\theta=1 .^{11}$ The probability $\rho$ that during an interval $\Delta t$ an entrepreneur finds skilled workers and the probability $\xi$ that skilled workers find skilled jobs thus become:

$$
\rho=\left\{\begin{array}{rr}
A & \text { when } \quad \theta \leq 1 \\
A \theta^{-1} & \text { when } \quad \theta>1
\end{array}\right.
$$

\footnotetext{
${ }^{11}$ When $\theta=1$, the number of skilled vacancies equals the number of skilled workers searching from jobs. In this case, the exit rates of entrepreneurs and workers from self-employment are both $A$. In what follows, we focus on one of the cases with shortages, i.e. shortage of skilled vacancies, $\theta<1$, or shortages of skilled workers, $\theta>1$.
} 


$$
\xi=\left\{\begin{aligned}
A & \text { when } \theta \geq 1 \\
A \theta & \text { when } \theta<1
\end{aligned}\right.
$$

Conditions (14) and (15) show the interdependence of outcomes of entrepreneurs and workers: If entrepreneurs increase their search effort from a situation of $\theta<1$ (shortage of skilled vacancies), probability that skilled workers find skilled jobs rises. If entrepreneurs increase their effort to the point where $\theta>1$, probability that workers find jobs rises to $A$, but probability that entrepreneurs find skilled workers falls. However, when making decisions about their search intensity, individual entrepreneurs take $\theta$ as given and disregard these external effects, which results in inefficient equilibrium outcomes. Below, we examine the cases where either skilled job openings are scarce or skilled workers are scarce. More emphasis is put on the case with shortages of skilled jobs, which describes the situation prevailing in most Africa's LDCs.

\section{Policy Analysis}

The economy laid out in the preceding section exhibits two main types of frictions (rigidities) where government interventions may be warranted: (i) in the labor market $(A<1)$ and (ii) in the business climate $(\varepsilon<1)$. Some of the countries are likely to face very high costs of setting up business, which in the model would be captured by low efficiency of the entrepreneurs' search cost, $\gamma$ or very high profit taxation, $\tau$. Moreover, due to imperfect information in the skilled workers' labor market, the quality of match may be low and hence the separation rate, $\delta$, high, with skilled workers failing to find the available jobs (low $A$ ). In economies where skill shortages are so severe that they inhibit firm creation (low $\bar{q}$ or high $\phi$ ), government support to training of workers could be warranted. Policies below, which aim at overcoming these bottlenecks, can be grouped into several categories according to the channels of transmission (Table 1).

Table 1. Policy instruments to support productive entrepreneurship

\begin{tabular}{|l|l|l|}
\hline $\begin{array}{l}\text { Stimulating search of } \\
\text { entrepreneurs (by raising } \\
\text { expected net profit) }\end{array}$ & $\begin{array}{l}\text { Improving availability of } \\
\text { skilled workers (through } \\
\text { training) }\end{array}$ & $\begin{array}{l}\text { Improving matching process } \\
\text { (by facilitating mobility and } \\
\text { information exchange) }\end{array}$ \\
\hline $\begin{array}{l}\text { Improving business } \\
\text { environment } \\
\text { (increasing } \varepsilon \text { ) }\end{array}$ & $\begin{array}{l}\text { Co-financing higher } \\
\text { education } \\
\text { (reducing } \phi)\end{array}$ & $\begin{array}{l}\text { Supporting entrepreneurs } \\
\text { search through training } \\
\text { (increasing } \gamma \text { ) }\end{array}$ \\
\hline $\begin{array}{l}\text { Reducing SME taxation } \\
\text { (lowering } \tau \text { ) }\end{array}$ & $\begin{array}{l}\text { Co-financing adult training } \\
\text { (reducing } \phi)\end{array}$ & $\begin{array}{l}\text { Improving information at the } \\
\text { skilled labor market } \\
\text { (increasing A) }\end{array}$ \\
\hline $\begin{array}{l}\text { Reducing start up cost } \\
\text { (increasing } \gamma \text { ) }\end{array}$ & $\begin{array}{l}\text { Improving information on } \\
\text { types of available skilled jobs } \\
\text { (reducing } \delta \text { ) }\end{array}$ & $\begin{array}{l}\text { Removing barriers to mobility } \\
\text { through language training, } \\
\text { housing (increasing A) }\end{array}$ \\
\hline
\end{tabular}


In what follows, we examine two cases: (i) when skilled jobs openings are scarce and (ii) when skilled workers are scarce. ${ }^{12}$

\section{The shortage of skilled job openings $(\theta<1)$}

Under this scenario, $\rho=A$ and $\xi=A \theta$, that is entrepreneurs with skilled vacancies are more likely to fill them than skilled workers to find skilled openings As specified in (4), entrepreneurs choose their search intensity, $x$, so that the marginal cost of search equals to the expected marginal payoff. Denoting $d=J^{p}-J^{u}$ to be the difference between the value of running a highly productive firm (with skilled workers) and being self-employed, this implies that $x=\gamma A d$. The equilibrium is then characterized by 3 equations in 3 unknowns - entrepreneurs' search effort, probability that skilled workers find skilled jobs and private sector wages $(x, \xi, w)$ :

$$
\begin{aligned}
& x(r+\delta)+A \frac{x^{2}}{2}=A \gamma[(1-\tau)(\varepsilon z \bar{n}-w \bar{n})-b] \\
& \xi=\frac{\delta A \mu \bar{n} x}{(1-\mu) \delta \bar{q}+(1-\mu-\mu \bar{n}) A x \bar{q}}
\end{aligned}
$$

and the wage equation (7). Equilibrium wage and entrepreneurs' search occur where (16) and (7) intersect, with $\zeta$ determined by (17). Exogenous shifts in any of the three equations affect both the probability that skilled workers can find jobs, $\xi$ (and their wages, $w$ ) and the intensity of entrepreneurs' search, $x$ (Table 2). Often, such shifts are caused by changes in policies or institutions. For example, improvements in the business environment, $\varepsilon$, increase the entrepreneurs' search, $x$. This in turn raises the probability that searching skilled workers find skilled jobs $\xi$ as well as their wage, $w$. Same holds about improvements in the efficiency of the entrepreneurs' search, $\gamma$. Assuming that $\mu \leq 1 /(1+\bar{n})$, i.e. the population of potential entrepreneurs is limited, the comparative statics are as in Table 2.

The results show that the steady state share of self-employed entrepreneurs searching for business opportunities in the formal sector is negatively related to improvements in the business climate, $\varepsilon$, the efficiency of search, $\gamma$, and the reduction in the profit tax rate, $\tau$. Moreover, in this case measures aimed at easing constraints on the firm side (improvements to the business environment, lowering of profit tax and improving conditions for entrepreneurs search) have unambiguously positive impact on skilled workers' chances of finding skilled jobs and the wage they receive as well as on entrepreneurs' search and start ups. While the improvement of the matching process $(A)$ impact positively skilled workers' probability of finding skilled jobs, it also raises wages. As firms' profitability declines, the impact on the entrepreneurs' search and hence the number of private firms is unclear. Similar observation applies to the quality of match as reflected in reducing the separation rate, $\delta$.

\footnotetext{
${ }^{12}$ The case with no shortages, i.e. $\theta=1 \Leftrightarrow V=N$, is not explicitly covered. However, its solution would be straightforward, with $\rho=\xi=A$. Policies favorable to entrepreneurship vary with different levels of GDP per capita, with skill shortages being more prominent in more developed economies (Acs et al., 2008).
} 
Table 2. Comparative statics under shortages of skilled vacancies 1/

\begin{tabular}{|c|c|c|}
\hline \multirow[b]{2}{*}{ Effects of an increase in } & \multicolumn{2}{|c|}{ On the equilibrium value of } \\
\hline & $\begin{array}{l}\text { Skilled workers' } \\
\text { probability of finding } \\
\text { skilled jobs } \\
\xi\end{array}$ & $\begin{array}{l}\text { The share of } \\
\text { entrepreneurs } \\
\text { searching for } \\
\text { opportunities } \\
m_{u}\end{array}$ \\
\hline Quality of the business environment, $\varepsilon$ & + & - \\
\hline Efficiency of entr. search, $\gamma$ & + & - \\
\hline Profit tax rate, $\tau$ & - & + \\
\hline Efficiency of matching, $A$ & + & ? \\
\hline Separation rate, $\delta$ & - & ? \\
\hline Rate of skill acquisition, $\bar{q}$ & - & no impact 2/ \\
\hline
\end{tabular}

Source: Author's calculations. 1/ ? denotes ambiguous impact. 2/ Improving rate of skill acquisition (or reducing cost of training would not have any impact on the number of searching entrepreneurs as long as the binding constraint would remain on the side of skilled vacancies.

As Table 2 shows, government policies need to address the binding constraints in order to stimulate private firm creation. For example, when skilled workers are abundant, government policies aimed at training and skill acquisition would be ineffective in supporting entrepreneurship. ${ }^{13}$ Further expenditures in these areas would only raise the share of skilled workers searching for jobs. However, this could lower workers' probability of finding skilled jobs, leading to a larger pool of educated workers in the informal sector. In this case the binding constraints to be addressed are on the side of job creation, in particular the business environment, taxation and start up costs.

\section{The shortage of skilled workers $(\theta>1)$}

Under this scenario, $\xi=A$ and $\rho=A \theta^{-1}$, that is skilled workers have higher changes of finding skilled jobs than entrepreneurs with skilled vacancies would find suitable workers. The equilibrium is again characterized by 3 equations in 3 unknowns $(x, \rho, w)$. In addition to entrepreneurs' search effort, $x$, and skilled workers' wage rate, $w$, probability that entrepreneurs with skilled vacancies find skilled workers, $\rho$, now needs to be determined:

$$
\begin{aligned}
& x(r+\delta)+\rho \frac{x^{2}}{2}=\gamma \rho[(1-\tau)(\varepsilon z \bar{n}-w \bar{n})-b] \\
& \rho=\frac{A \delta(1-\mu) \bar{q}}{[\mu \delta \bar{n}-(1-\mu-\mu \bar{n}) \bar{q} A] x \bar{n}}
\end{aligned}
$$

\footnotetext{
${ }^{13}$ Any increase in the rate of skill acquisition is completely offset by the lower probability of workers finding a job.
} 
Wage is again determined through the wage equation (7). Equilibrium wage, $w$, and entrepreneurs' search, $x$, occur where (18) and (7) intersect, with probability of finding skilled workers, $\rho$, determined by (19). The comparative statics are:

Table 3. Comparative statics under shortages of skilled workers

\begin{tabular}{|l|c|c|}
\hline \multicolumn{1}{|c|}{ Effects of an increase in } & On the equilibrium value of \\
\cline { 2 - 3 } & $\rho$ & $n_{u}$ \\
\hline Business environment, $\varepsilon$ & - & no impact \\
\hline Efficiency of entr. search, $\gamma$ & - & no impact \\
\hline Profit tax rate, $\tau$ & + & no impact \\
\hline Efficiency of matching, $A$ & + & - \\
\hline Separation rate $\delta$ & + & + \\
\hline Rate of skill acquisition, $\bar{q}$ & + & - \\
\hline
\end{tabular}

Source: Author's calculations.

Self-employment of workers in the informal sector is negatively related to the improved efficiency of matching, $A$, and to the increased rate of skill acquisition, $\bar{q}$. In Table 3 , it is particularly worth noting that with the relative abundance of firms searching for skilled workers, government policies aiming at improvements of the business environment and other bottlenecks on the side of firm creation alone would not generate highly productive (skilled) jobs. Increased government expenditures on training that would raise the rate of skill acquisition would be more effective. ${ }^{14}$

\section{Simulations}

To further illustrate how changes in policies and institutions can impact labor market outcomes, simulations are preformed, using equations (3) and (16) - (20). The benchmark equilibrium is Case I above (with shortages of private firms with skilled vacancies). This is because in most Africa's least developed countries the more binding constraint seems to be the lack of private firms with "good" jobs (highly productive and well-paid jobs), the absolute low skill level prevalent in these countries notwithstanding. Experiences of more developed countries indicate that with rapid private sector growth and increased complexity of production, skill shortages could start impeding private firm creation and eventually become the binding constraint.

Simulations for Case I have been performed with the baseline parameters as detailed in Table $4 .{ }^{15}$

\footnotetext{
14 Policies encouraging training would be effective as long as they would not lead to excessively high wages and thus discourage firm creation to the point that firms with skilled vacancies would become scarce.

${ }^{15}$ To the extent possible parameters reflect labor market in these countries. For example, the 50\% share of the informal sector is its share in Ethiopia, and so does the $30 \%$ gap between the formal and informal sector wages. However, the data is not adequate to conduct a full-fledged calibration exercise.
} 
Table 4. Baseline parameters

\begin{tabular}{|l|l|l|l|l|l|l|l|l|l|l|l|l|l|}
\hline Parameter & $\mathrm{A}$ & $\mu$ & $k$ & $\delta$ & $\gamma$ & $\bar{q}$ & $\varepsilon$ & $z$ & $\phi$ & $\bar{n}$ & $r$ & $b$ & $\tau$ \\
\hline Value & 0.5 & 0.3 & 1 & 0.2 & 1 & 1 & 0.45 & 2 & 0.3 & 3 & 0.1 & 0.385 & 0.3 \\
\hline
\end{tabular}

With these parameters, steady state values of the key variables of the model (self-employment, private sector entrepreneurs, workers in the formal sector, wages and probability of skilled workers finding skilled jobs) become as detailed in Table 5.

Table 5. Steady state values under the baseline parameters (shortage of skilled vacancies)

\begin{tabular}{|l|c|}
\hline Self-employment (\% of LF) 1/ & 50.1 \\
\hline Entrepreneurs operating high-prod. Firms (\% of LF) & 12.5 \\
\hline Workers employed in high prod. firms (\% of LF) & 37.5 \\
\hline Skilled wages (units of cons. good) & 0.62 \\
\hline Probability that skilled worker finds skilled job & 0.23 \\
\hline Entrepreneur's search effort (unit of cons. good) & 0.29 \\
\hline
\end{tabular}

1/ Includes both workers and potential entrepreneurs searching for business opportunities.

The elasticity of self-employed workers, searching entrepreneurs, skilled wages and probability that skilled workers find skilled jobs to changes in each of the policy variables $\varepsilon, \gamma, \tau, \delta$, $A$ may be calculated by changing values of these variables by 20 percent and computing the new equilibrium values. The impact of changing the rate of skill acquisition (due to government support to co-financing training cost) is also considered (Table 6).

Table 6. Elasticities of key macroeconomic variables to changes in policies

\begin{tabular}{|l|l|l|l|l|l|l|c|}
\hline $\begin{array}{l}\text { Policy } \\
\text { variable }\end{array}$ & $\begin{array}{l}\text { New } \\
\text { value }\end{array}$ & $\begin{array}{l}\text { Self- } \\
\text { empl. }\end{array}$ & $\begin{array}{l}\text { Share of } \\
\text { entrepr. } \\
\text { in LF }\end{array}$ & $\begin{array}{l}\text { Skilled } \\
\text { wages }\end{array}$ & $\begin{array}{l}\text { Entr. } \\
\text { search }\end{array}$ & $\begin{array}{l}\text { Probability } \\
\text { finding } \\
\text { skilled job }\end{array}$ & $\begin{array}{l}\text { Elasticity of self- } \\
\text { empl. to 20 \% } \\
\text { change in variable }\end{array}$ \\
\hline & & \multicolumn{2}{|c|}{$\begin{array}{l}\text { Units of cons } \\
\text { \% change }\end{array}$} \\
\hline$\varepsilon$ & 0.54 & 40.3 & 15.0 & 0.75 & 0.40 & 0.36 & -19.6 \\
\hline$\tau$ & 0.36 & 51.9 & 12.0 & 0.60 & 0.27 & 0.21 & 3.6 \\
\hline$\gamma$ & 1.20 & 48.8 & 12.8 & 063 & 0.30 & 0.24 & -2.6 \\
\hline$\delta$ & 0.24 & 58.3 & 10.4 & 0.62 & 0.26 & 0.19 & 16.4 \\
\hline $\mathrm{A}$ & 0.60 & 47.7 & 13.1 & 0.64 & 0.26 & 0.26 & -4.8 \\
\hline $\bar{q}$ & 1.20 & 50.1 & 12.5 & 0.62 & 0.29 & 0.19 & 0 \\
\hline
\end{tabular}

Source: Author's calculations.

The results presented in Table 6 are consistent with those in Table 2 in previous section (Case I shortages of private firms with skilled vacancies). They illustrate that improvements in the business climate (higher $\varepsilon$ ) and reduction in start up costs (higher $\gamma$ ) would reduce selfemployment in the informal sector and raise the number of highly-productive firms and skilled employment in the formal sector. The increase in tax rates $\tau$ would have an opposite effect. Productive entrepreneurship and skilled employment can be also encouraged through increased information availability and thus improved efficiency as well as the quality of the matching 
process (higher $A$ and lower $\delta$ ). Finally, reducing cost of entrepreneurial search, including through training of entrepreneurs (higher $\gamma$ ), would yield positive outcomes. ${ }^{16}$

Among the various policy measures examined, by raising productivity improvements in the business environment can be expected to have particularly high effect on reducing selfemployment and creating skilled jobs. Investment in physical capital (including in infrastructure) and institutional reforms that enhance productivity would have similar impact.

\section{Conclusions}

Which government interventions can foster the emergence of productive entrepreneurship in Africa's LDCs? The answer to this question matters, as absence of such entrepreneurship in these countries has hampered their productivity, creation of skilled jobs, innovation, and poverty reduction. To shed some light on these issues, this paper has developed a theoretical framework of obstacles to productive entrepreneurship in the formal sector of Africa's LDCs, modeling constraints both on the side of entrepreneurs and workers. While an abundant descriptive, survey and empirical literature on the topic of entrepreneurship and development in low income countries exists, theoretical studies have so far been rare. ${ }^{17}$ This paper contributes to closing this gap with a model that captures some of the main constraints faced by entrepreneurs in Africa's LDCs, including their own skill shortages and those of potential workers.

The model developed in this paper reflects also several key stylized facts of the African labor markets, including the abundance of the necessity and the scarcity of the opportunity entrepreneurship. The policy analysis shows that government interventions may help stimulate private sector take-off. However, given the scarcity of budgetary resources and the numerous constraints, policy actions need to be well-targeted and address the most pressing ones to be effective. In an economy characterized by the scarcity of skilled job openings, policymakers should aim at removing obstacles to firm creation such as poor business climate, high taxation of excessive start up costs. In turn, where skilled workers are scarce, training policies may be most effective. Since in a dynamic economy the binding constraints to productive entrepreneurship constantly evolve, the importance of policy selectivity and sequencing cannot be overstated.

In addition to policies intended to overcome constraints to firm entry and skill bottlenecks, other active labor market policies, especially information exchange between available jobs and searching workers, could play a positive role. Specifically, with better information, the efficiency of the matching process between skilled openings and workers would rise while search time would decrease. The quality of jobs matches and job duration would also improve. Finally, future research could examine policies to mitigate credit constraints in the post-crisis world, as these constraints became even more binding due to the global financial crisis and the increased cost of credit that it brought about for Africa's SMEs.

\footnotetext{
${ }^{16}$ Training could be on, for example, writing business proposals, setting up businesses, and networking. See, for example, World Economic Forum (2009) and Martinez et al. (2010).

${ }^{17}$ Gelb et al. (2009) is an exception as the authors develop a simple model of entrepreneurship in Southern and Eastern Africa and their decisions regarding formalization.
} 


\section{Annex I - Africa's 10 Least Developed Countries: The Facts}

The disproportionate share of agriculture in GDP, low GDP growth and low literacy rates characterize Africa's LDCs...

Table 1. Africa's LDCs: Selected Indicators

\begin{tabular}{|c|c|c|c|c|}
\hline & $\begin{array}{l}\text { GDP per } \\
\text { capita, US\$, } \\
2000 \text { prices) }\end{array}$ & $\begin{array}{l}\text { Share of } \\
\text { agriculture } \\
\text { in value } \\
\text { added in } \\
2007(\%)\end{array}$ & $\begin{array}{l}\text { Average } \\
\text { annual real } \\
\text { GDP } \\
\text { growth, } \\
2005-08 \\
(\%)\end{array}$ & $\begin{array}{l}\text { Adult literacy rates } \\
\text { (\% of population } \\
\text { aged } 15 \text { and above, } \\
1999-2007 \text { ) }\end{array}$ \\
\hline Burundi & 113 & 32 & 2.4 & 59 \\
\hline Central African Rep. & 223 & 53 & 1.9 & 49 \\
\hline Congo Dem. Rep. & 101 & 40 & 3.6 & 67 \\
\hline Ethiopia & 180 & 43 & 6.8 & 36 \\
\hline Guinea Bissau & 141 & 61 & 1.4 & 65 \\
\hline Liberia & 134 & 66 & 3.7 & 56 \\
\hline Malawi & 182 & 30 & 3.8 & 72 \\
\hline Niger & 190 & 41 & 4.4 & 29 \\
\hline Sierra Leone & 247 & 42 & 10.3 & 38 \\
\hline Togo & 222 & 43 & 1.3 & 53 \\
\hline sub-Saharan Africa & 684 & 15 & 5.8 & 62 \\
\hline LDCs (UN classification) & 375 & 25 & $\ldots$ & $\ldots$ \\
\hline
\end{tabular}

Sources: African Economic Outlook database, World Bank Development Indicators database, and United Nations Human Development Report database.

The business environment and the rule of law are also weaker than in other African countries ...

Figure 1. Rule of law and GDP per capita: Africa’s LDCs and other countries, 2008 1/

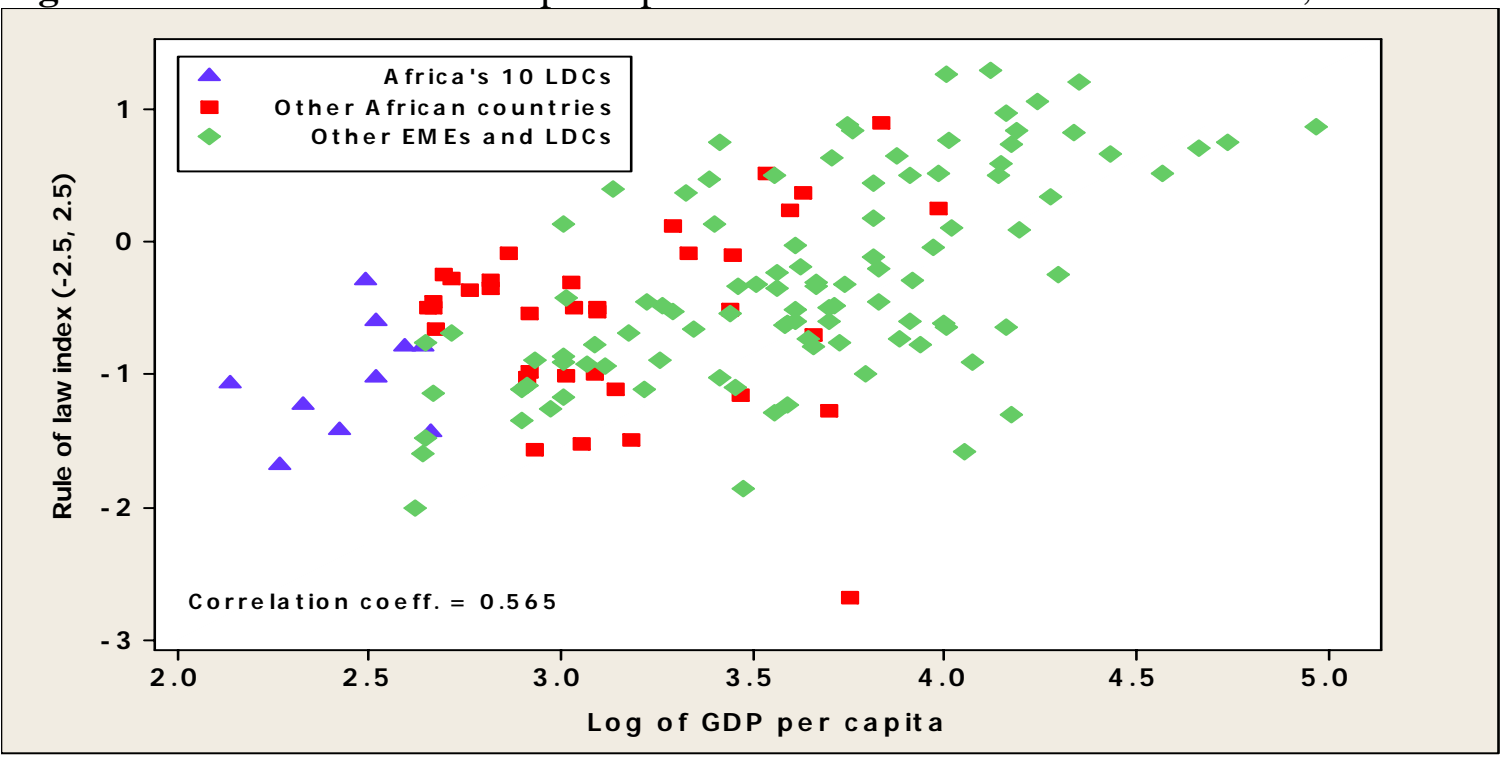

Source: World Bank Governance database. 1/ Excludes Eritrea and Zimbabwe. 
Africa suffers from the human capital gap...

Figure 2a. Education index (2009) and GDP per capita (2008) 1/

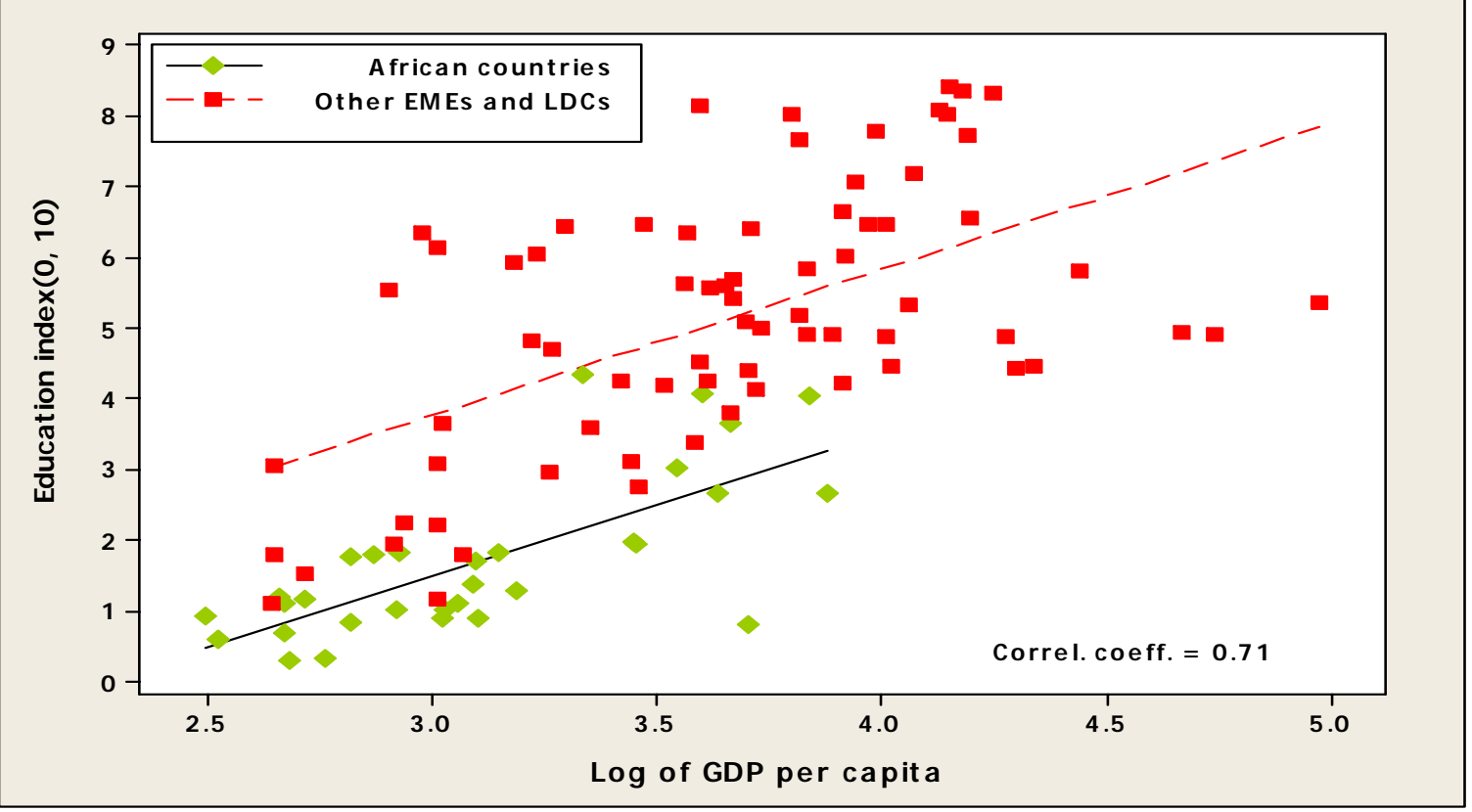

Source: World Bank Knowledge Economy database. 1/ EMEs and developing countries in KAM database.

...and skill shortages in Africa's LDC seem particularly pronounced...

Figure 2b. Unskilled workers in manufacturing firms in Africa’s LDCs, 2006

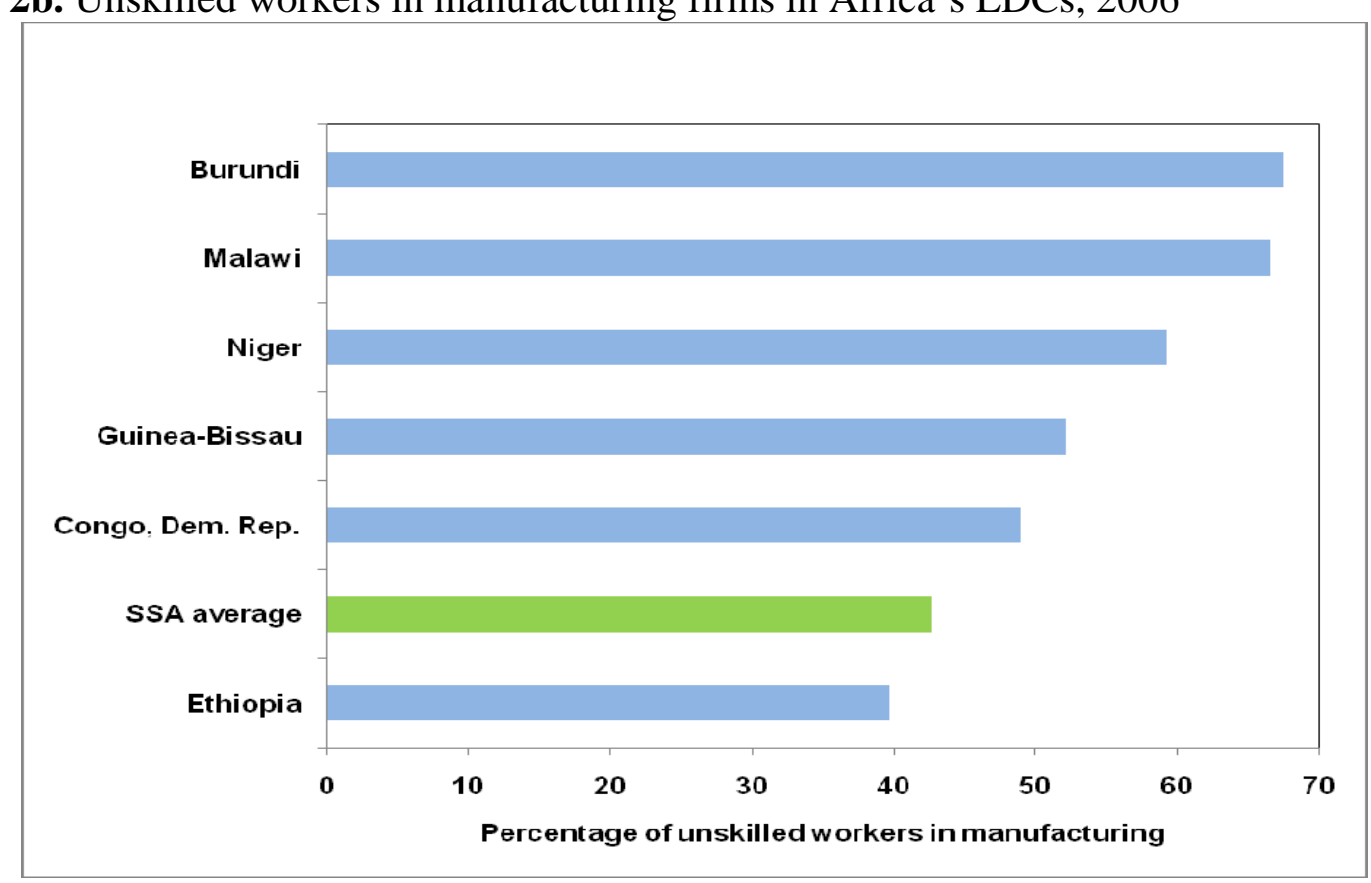

Source: World Bank Enterprise Survey database. 


\section{References}

Acs, Z. J., Desai, S. and Hessels, J. (2008), Entrepreneurship, economic development and institutions, Small Business Economics, Vol. 31, 219-234.

Acs, Z. J.; Arenius, P.; Hay, M. and Minniti, M. (2005), Global Entrepreneurship Monitor: 2004 Executive Report, Babson College and London Business School.

Acs, Z. J. and Varga, A. (2005), Entrepreneurship, agglomeration and technological change, Small Business Economics, Vol. 24 (3), 323-334.

African Development Bank and the Organization for Economic Cooperation and Development (2005), Financing SME development in Africa, in African Economic Outlook, AfDB, Tunis and OECD, Paris.

Baliamoune-Lutz, M. (2009), Entrepreneurship and reforms in developing countries, UNUWIDER Research Paper No. 4/2009.

Baliamoune-Lutz, M. (2007), Entrepreneurship, reforms and development: Empirical evidence, ICER Working Paper No. 38/2007, Turin: International Centre for Economic Research.

Baumol, W. J. (1990), Entrepreneurship: Productive, unproductive and destructive, Journal of Political Economy, Vol. 98 (5), 893-921.

Bonaglia, F. and Fukasaku, K. (2007), Private sector development in poor countries: Seeking better policy recipes? OECD Development Center Policy Insights, No. 48.

Brixiova, Z. and Asaminew, E. (2009), On SME start ups in Ethiopia: Which incentives matter? Paper presented at the 2009 African Economic Conference (Addis Ababa).

Brixiova Z. and Kiyotaki N. (1997), Private sector development in transition economies, Carnegie-Rochester Conference Series on Public Policy, Vol. 46, 241 - 280.

Commission on the Private Sector and Development (2004), Unleashing Entrepreneurship: Making Business Work for the Poor, Report to the Secretary-General of the United Nations.

Davidson, P. and Henrekson, M. (2002), Determinants of the prevalence of start ups and highgrowth firms, Small Business Economics, Vol. 19, 81 - 104.

Gelb, A.; Mengistae, T.; Ramachandran, V., and Shah, M. K. (2009), To formalize or not to formalize? Comparisons of microenterprise data from Southern and East Africa, Center for Global Development Working Paper No. 175.

Gelb, A., Ramachandran, V. and Turner, G. (2007), Stimulating growth and investment in Africa: From macro to micro reforms, African Development Review, Vol. 19, Issue 1, 26-51. 
Leff, N. H. (1979), Entrepreneurship and economic development: The problem revisited, Journal of Economic Literature, Vol. XVII (March), 46 - 64.

Li, W. (1998), Government loan, guarantee and grant programs: An evaluation, Federal Reserve Bank of Richmond Economic Quarterly (Fall), 25-51.

Martinez, A. C.; Levie, J.; Kelley, D. J.; Sæmundsson, R. J.; Schøtt, T., and the Global Entrepreneurship Research Association (2010), A Global Perspective on Entrepreneurial Education and Training, Global Entrepreneurship Special Report.

Naudé, W. (2010), Promoting entrepreneurship in developing countries: Policy challenges, UNU-WIDER Policy Brief, No. 4.

Rogerson, C. M. (2001), In search of the African miracle: debates on successful small enterprise development in Africa, Habitat International, Vol. 25, 115-142.

Snower, D., (1996), The low-skill, bad-job trap, in: Booth, A., Snower, D. (Eds.), in Acquiring Skills: Market failures, their Symptoms and Policy Responses, Cambridge University Press, New York, 109-128.

World Economic Forum (2009), Educating the Next Wave of Entrepreneurs: Unlocking Entrepreneurial Capabilities to Meet the Global Challenges of the $21^{\text {st }}$ Century, WEF: Geneva. 


\section{DAVIDSON INSTITUTE WORKING PAPER SERIES - Most Recent Papers}

The entire Working Paper Series may be downloaded free of charge at: www.wdi.umich.edu

CURRENT AS OF $6 / 14 / 10$

\begin{tabular}{|c|c|c|}
\hline Publication & Authors & Date \\
\hline $\begin{array}{l}\text { No. 990: UNLOCKING PRODUCTIVE ENTREPRENEURSHIP IN AFRICA'S LEAST } \\
\text { DEVELOPED COUNTRIES }\end{array}$ & Zuzana Brixiova & June 2010 \\
\hline $\begin{array}{l}\text { No. 989: The VARying Effect of Foreign Shocks in Central \& Eastern } \\
\text { Europe }\end{array}$ & $\begin{array}{l}\text { Rebeca Jimenez-Rodriguez, } \\
\text { Amalia Morales-Zumaquero } \\
\text { \& Balazs Egert }\end{array}$ & May 2010 \\
\hline $\begin{array}{l}\text { No. 988: Implications of Bank Ownership for the Credit Channel of } \\
\text { Monetary Policy Transmission: Evidence from India }\end{array}$ & $\begin{array}{l}\text { Sumon K. Bhaumik, Vinh Dang } \\
\text { and Ali M. Kutan }\end{array}$ & May 2010 \\
\hline $\begin{array}{l}\text { No. 987: Mother or motherland: Can a government have an impact on } \\
\text { educational attainment of the population? Preliminary evidence from } \\
\text { India }\end{array}$ & $\begin{array}{l}\text { Sumon Kumar Bhaumik and } \\
\text { Manisha Chakrabarty }\end{array}$ & May 2010 \\
\hline $\begin{array}{l}\text { No. 986: Does FDI spur innovation, productivity and knowledge sourcing } \\
\text { by incumbent firms? Evidence from manufacturing industry in Estonia }\end{array}$ & Priit Vahter & April 2010 \\
\hline No. 985: Exports and Property Prices in France: Are They Connected? & $\begin{array}{c}\text { Balazs Egert and } \\
\text { Rafal Kierzenkowski }\end{array}$ & May 2010 \\
\hline $\begin{array}{l}\text { No. 984: Methodologies of Analyzing Inter-Regional Income Inequality } \\
\text { and Their Applications to Russia }\end{array}$ & Konstantin Gluschenko & April 2010 \\
\hline $\begin{array}{l}\text { No. 983: Foreign News and Spillovers in Emerging European Stock } \\
\text { Markets }\end{array}$ & Evzen Kocenda and Jan Hanousek & $\begin{array}{l}\text { May } \\
2010\end{array}$ \\
\hline $\begin{array}{l}\text { No. 982: The Economic and Monetary Union's effect on (international) } \\
\text { trade: the case of Slovenia before euro adoption }\end{array}$ & $\begin{array}{l}\text { Aleksander Aristovnik and } \\
\text { Matevz Meze }\end{array}$ & $\begin{array}{l}\text { April } \\
2010\end{array}$ \\
\hline $\begin{array}{l}\text { No. 981: In Time of Troubles: Challenges and Prospects in the Middle } \\
\text { East and North Africa }\end{array}$ & Imed Drine & $\begin{array}{l}\text { April } \\
2010\end{array}$ \\
\hline No. 980: A Composite Leading Indicator of Tunisian Inflation & Mohamed Daly Sfia & $\begin{array}{l}\text { March } \\
2010\end{array}$ \\
\hline $\begin{array}{l}\text { No. 979: Financial stability, monetary autonomy and fiscal interference: } \\
\text { Bulgaria in search of its way, 1879-1913 }\end{array}$ & $\begin{array}{l}\text { Kalina Dimitrova and } \\
\text { Luca Fantacci }\end{array}$ & Feb 2010 \\
\hline $\begin{array}{l}\text { No. 978: The Supply Side of Innovation: H-1B Visa Reforms and US } \\
\text { Ethnic Invention }\end{array}$ & $\begin{array}{l}\text { William R. Kerr and } \\
\text { William F. Lincoln }\end{array}$ & Feb 2010 \\
\hline $\begin{array}{l}\text { No. 977: Data Collection Procedures Equivalence in International } \\
\text { Business Research }\end{array}$ & $\begin{array}{l}\text { Agnieszka Chidlow, } \\
\text { Anna Morgan-Thomas } \\
\text { and Pervez N. Ghauri }\end{array}$ & Feb 2010 \\
\hline $\begin{array}{l}\text { No. 976: Direct and Indirect Effects of FDI in Emerging European } \\
\text { Markets: A Survey and Meta-analysis }\end{array}$ & $\begin{array}{l}\text { Jan Hanousek, Evzen Kocenda } \\
\text { and Mathilde Maurel }\end{array}$ & $\begin{array}{l}\text { March } \\
2010\end{array}$ \\
\hline $\begin{array}{l}\text { No. 975: MODELING INSTITUTIONS, START-UPS AND PRODUCTIVITY DURING } \\
\text { TRANSITION }\end{array}$ & $\begin{array}{l}\text { Zuzana Brixiová and } \\
\text { Balázs Égert }\end{array}$ & Feb 2010 \\
\hline $\begin{array}{l}\text { No. 974: Pegging the future West African single currency in regard to } \\
\text { internal/external competitiveness: a counterfactual analysis }\end{array}$ & $\begin{array}{l}\text { Gilles Dufrénot and } \\
\text { Kimiko Sugimoto }\end{array}$ & Dec 2009 \\
\hline $\begin{array}{l}\text { No. 973: Unemployment and finance: how do financial and labour market } \\
\text { factors interact? }\end{array}$ & $\begin{array}{l}\text { Donatella Gatti, Christophe Rault } \\
\text { \& Anne-Gaël Vaubourg }\end{array}$ & $\begin{array}{l}\text { January } \\
2010\end{array}$ \\
\hline No. 972: Identifying Social Entrepreneurs Serving the Poor at the BoP & Abraham M. George & $\begin{array}{l}\text { December } \\
2009\end{array}$ \\
\hline $\begin{array}{l}\text { No. 971: Inflation dynamics and the New Keynesian Phillips curve in the } \\
\text { EU-4 }\end{array}$ & Bořek Vašíček & $\begin{array}{l}\text { October } \\
2009\end{array}$ \\
\hline $\begin{array}{l}\text { No. 970: International Financial Integration And Real Exchange Rate } \\
\text { Long-Run Dynamics In Emerging Countries: Some Panel Evidence }\end{array}$ & $\begin{array}{l}\text { Guglielmo Maria CAPORALE, } \\
\text { Thouraya HADJ AMOR } \\
\text { and Christophe RAULT }\end{array}$ & Sept 2009 \\
\hline $\begin{array}{l}\text { No. 969: Once Bitten, Twice Shy: Experiences Of A Banking Crisis } \\
\text { And Expectations Of Future Crises }\end{array}$ & Shannon Mudd \& Neven Valev & Sept 2009 \\
\hline
\end{tabular}

